\title{
Evaluation of three rape seed commodities in the rumen of steers 2. Degradation of fibre fractions and disappearance of macrominerals in situ
}

\author{
K.-H. Südekum, Helga Andree ${ }^{1}$ and D. Höhler
}

\author{
Institute of Animal Nutrition, Physiology and Metabolism, \\ Christian-Albrechts-University \\ D-24098 Kiel, Germany
}

(Received 11 July 1996; accepted 6 February 1997)

\begin{abstract}
Rate and extent of ruminal degradation of detergent fibre fractions and disappearance of macromincrals ( $\mathrm{Ca}, \mathrm{P}, \mathrm{Mg}, \mathrm{Na}$ ) of rape seed and of untrcated and tormaldehyde-treated rapesecd meals containing less than $8 \mu \mathrm{mol}$ glucosinolates per gram of dry matter were investigated. Feeds were incubated in polyester bags in the rumen of three fistulated steers for $0,2,4,8,16,24$ and $48 \mathrm{~h}$. Degradation characteristics of fibre fractions indicated that rapesed fibre can be more degradable than previously assumed. The rape seed had the most degradable neutral and acid detergent fibre fractions. Fibre frictions of the formaldehyde-treated rapeseed meal were more degradable than those of the untreated meal. The effective degradabilities of neutral detergent tibre at assumed ruminal passage rates of 2,5 and $8 \% / \mathrm{h}$ ranged from 62 to $53 \%$ for the rape seed, 52 to $38 \%$ for the untreated meal and 65 to $49 \%$ for the formaldehyde-treated meal. The three rape seed commodities were a good source of macrominerals for ruminants, as indicated by macromineral concentrations in the feeds and by pattern and extent of ruminal disappearance of the minerals. The rape seed had a faster rate of disappearance of most macrominerals than the two meals. In contrast to fibre, macrominerals tended to disappear at a faster rate from the untreated meal than from the formaldehyde-treated meal.
\end{abstract}

KEY WORDS: rape seed, rapeseed meal, formaldchyde, rumen degradation, fibre, macrominerals

${ }^{1}$ Current address: Institute of Agricultural Engineering, Christian- Albrechts-University, 24098 Kiel, Germany 


\section{INTRODUCTION}

Although rapeseed meal (RSM) competes with protein-rich supplements in the diet of ruminants, RSM contains considerable levels of non-protein constituents. It has been reported to contain 30\% hulls (Bell and Shires, 1982), which are mainly composed of cell-wall components. Hulls of autumn sown varieties of rape seed (Brassica napus) contained 49 to $54 \%$ neutral detergent fibre (NDF), 34 to $53 \%$ acid detergent fibre (ADF) and 18 to $26 \%$ acid detergent lignin (ADL) (Grenet and Barry, 1990; Keller et al., 1995). When rape seed hulls were incubated in the rumen in situ, only $61 \%$ of hull dry matter (DM) had disappeared after $72 \mathrm{~h}$ (Grenet and Barry, 1990). McKinnon et al. (1995) reported that effective ruminal NDF and ADF degradabilities of canola (B. campestris) hulls at an estimated ruminal passage rate of $5 \% / \mathrm{h}$ were as low as 19 and $12 \%$, respectively. Assuming a passage rate of $2.5 \% / \mathrm{h}$, however, Tamminga et al. (1990) reported an effective ruminal NDF degradability of $60 \%$ for RSM. To the authors knowledge, no other studies report on ruminal fibre degradation of whole rape seed or RSM.

Rapeseed meal contains a relatively high amount of $\mathrm{P}$ (Kirby and Nelson, 1988) and other macrominerals (Bell, 1993). Little research has been carried out on mineral availability in ruminants. Ingalls and Okemo (1994) reported that in situ disappearance of $\mathrm{P}$ of five different samples of canola meal varied from 36 to $53 \%$ after $12 \mathrm{~h}$, and from 64 to $78 \%$ after $16 \mathrm{~h}$ of ruminal incubation, respectively. These values were lower than those found for a soyabean meal used in the same study (60 and $77 \%$ after 12 and $16 \mathrm{~h}$, respectively; Ingalls and Okemo, 1994).

The objectives of this study were to determine characteristics of ruminal fibre degradation and of macromineral disappearance after in situ ruminal incubation of three rape seed commodities.

\section{MATERI $\Lambda$ L $\Lambda$ ND METHODS}

Rape seed commodities

Three commercially available rape seed commodities, rape seed, RSM and formaldehyde-treated RSM (FRSM; Bioprofin ${ }^{\cdot \bar{R}}$ ), were used. The proximate constituent composition of the feeds was reported previously (Südekum and Andree, 1997). Fibre, macromineral, total glucosinolate and formaldehyde concentrations of the three commodities are presented in Table 1. 
TABLE 1

Concentrations of fibre fractions, macrominerals, formaldehyde and glucosinolates in the rape seed commodities, g/kg dry matter

\begin{tabular}{lccc}
\hline & Rape seed & Rapesecd meal & $\begin{array}{c}\text { Formaldehyde-treated } \\
\text { rapeseed meal }\end{array}$ \\
\hline Neutral detergent fibre & 397 & 335 & 395 \\
Acid detergent fibre & 317 & 229 & 225 \\
Acid detergent lignin & 152 & 97 & 102 \\
Calcium & 4.5 & 7.3 & 7.5 \\
Phosphorus & 9.2 & 10.9 & 11.2 \\
Magnesium & 3.2 & 4.5 & 1.6 \\
Sodium & 0.2 & 1.3 & 0.9 \\
Formaldehyde & ND & ND & 0.88 \\
Total glucosinolates, $\mu \mathrm{mol} / \mathrm{g} \mathrm{DM}$ & 7.6 & 6.5 & 7.0 \\
\hline
\end{tabular}

${ }^{\text {a }}$ not determined

\section{Animals, feeding and in situ procedure}

The steers and feeding used in this trial were described by Südekum and Andree (1997). A previous paper (Südekum and Andree, 1997) emphasized data regarding ruminal degradation of DM and crude protein and ruminal disappearance of amino acids. The in situ procedure and calculations of ruminal fibre and macromineral disappearance and of fibre degradation and effective fibre degradabilities were performed as presented in detail for DM and crude protein in the previous paper (Südekum and Andree, 1997). Briefly, polyester bags were incubated in the rumens of three steers for $0,2,4,8,16,24$ and $48 \mathrm{~h}$. Water soluble material was estimated by washing a sample through filter paper. Values for water-soluble material were subtracted from 0 -h values to yield small particles escaping from the bags during washing. Values for fibre and macromineral disappearance at incubation times of 0 to $48 \mathrm{~h}$ were then corrected for small particles as outlined by Weisbjerg et al. (1990). Degradation parameters and effective degradabilties of NDF and ADF were calculated according to McDonald (1981), the latter at assumed rumen solid outflow rates of 2, 5 and $8 \%$ per $\mathrm{h}$, which is representative for low, medium, and high feeding amounts (Agricultural Research Council, 1984).

\section{Chemical analysis}

Feedstuffs and residues from polyester bag incubations were prepared, dried and analysed for formaldehyde (in FRSM only) and total glucosinolates as 
reported previously (Südekum and Andree, 1997). Dried residues were pooled by feedstuff and incubation time for fibre and macromineral analyses resulting in one observation per feedstuff and incubation time ( 7 observations per feedstuff including 0 -h values). Detergent fibre fractions in the feedstuff's and residues from polyester bag incubations were determined according to Van Soest et al. (1991). The detergent fibre analyses were performed without the use of decalin. Sodium sulphite was omitted and tricthylene glycol was used instead of 2-ethoxyethanol in the NDF procedure. Macromineral analyses were performed photometrically $(\mathrm{P})$ and by atomic absorption spectroscopy $(\mathrm{Ca}, \mathrm{Mg}$ ) or flame spectroscopy (Na) according to Bassler (1976).

\section{RESULTS}

Data on ruminal disappearance of NDF and ADF are reported in Table 2. Because fibre and macromineral analyses were performed on pooled samples, no statistical evaluation of the data could be conducted. For rape seed and FRSM, the values of NDF disappearance increased continuously from 0 to $48 \mathrm{~h}$ of runinal incubation. The ADF disappearance values of rape seed and FRSM were maximized after 16 and $24 \mathrm{~h}$ of ruminal incubation, respectively. The NDF

TABLE 2

Effect of ruminal incubation time on disappearance (\%) of neutral detergent fibre (NDF) and acid detergent fibre (ADF) from polyester bags

\begin{tabular}{|c|c|c|c|c|c|c|c|c|}
\hline & \multirow{2}{*}{$\begin{array}{c}\text { Washing } \\
\operatorname{loss}^{b}\end{array}$} & \multicolumn{7}{|c|}{ Incubation time, $\mathrm{b}$} \\
\hline & & 0 & 2 & 4 & 8 & 16 & 24 & 48 \\
\hline \multicolumn{9}{|c|}{ Rapc seed } \\
\hline NDF & 36.9 & 13.6 & 38.0 & 44.8 & 54.6 & 63.3 & 66.3 & 68.9 \\
\hline $\mathrm{ADF}$ & 50.4 & 52.5 & 64.4 & 66.3 & 68.2 & 73.0 & 74.4 & 75.8 \\
\hline \multicolumn{9}{|c|}{ Rapeseed meal } \\
\hline $\mathrm{NDF}^{*}$ & 15.2 & 9.0 & 7.1 & 15.4 & 33.4 & 49.3 & 52.6 & 61.7 \\
\hline $\mathrm{ADF}$ & 32.5 & 10.5 & 6.9 & 10.3 & 23.6 & 31.8 & 29.8 & 38.1 \\
\hline \multicolumn{9}{|c|}{$\begin{array}{l}\text { Formaldehyde-Ireated } \\
\text { rapeseed meal }\end{array}$} \\
\hline NDF & -7.0 & 31.6 & 43.5 & $44 . i$ & 46.6 & 61.0 & 67.8 & 75.9 \\
\hline $\mathrm{ADF}$ & 18.9 & 33.6 & 41.2 & 41.6 & 43.9 & 53.9 & 57.5 & 57.5 \\
\hline
\end{tabular}


TABLE 3

Nonlinear estimates and effective degradability values of neutral detergent fibre (NDF) and acid detergent fibre (ADF)

\begin{tabular}{|c|c|c|c|c|c|c|c|c|}
\hline & \multirow[b]{2}{*}{$a^{3}$} & \multirow[b]{2}{*}{$b$} & \multirow[b]{2}{*}{$\mathrm{c}$} & \multirow[b]{2}{*}{ Latg } & \multirow[b]{2}{*}{ Undegraded $^{\mathfrak{c}}$} & \multicolumn{3}{|c|}{ Effective degradability ${ }^{\mathrm{a}}$} \\
\hline & & & & & & $2 \%$ & $5 \%$ & $8 \%$ \\
\hline \multicolumn{9}{|c|}{ Rape seed } \\
\hline NDF & 15.5 & 50.9 & 22.0 & 0 & 33.6 & 62.1 & 56.9 & 52.8 \\
\hline ADF & 53.8 & 20.3 & 23.7 & 0 & 25.9 & 72.5 & 70.6 & 69.0 \\
\hline \multicolumn{9}{|c|}{ Rapeseed meal } \\
\hline NDF & 8.1 & 52.3 & 11.0 & 2.5 & 39.6 & 52.4 & 44.1 & 38.4 \\
\hline $\mathrm{ADF}$ & 8.7 & 26.3 & 15.9 & 3.5 & 65.0 & 31.7 & 25.5 & 21.7 \\
\hline \multicolumn{9}{|c|}{$\begin{array}{l}\text { Formaldehyde-treated } \\
\text { rapeseed meal }\end{array}$} \\
\hline NDF & 34.4 & 45.3 & 5.3 & 0 & 20.3 & 65.2 & 54.4 & 48.8 \\
\hline ADF & 34.6 & 24.3 & 8.7 & 0 & 41.1 & 50.6 & 45.8 & 43.0 \\
\hline
\end{tabular}

${ }^{2}$ effective degradability at three ruminal passage sates

${ }^{b} \mathrm{a}=$ the portion (percentage) of NDF or ADF solubilized at initiation of incubation; $b=$ the fraction (percentage) of NDF or ADF insoluble but degradable in the rumen; $\mathrm{c}=$ the constant rate (percentage per hour) of disappearanee of fraction $b$; lag $=$ lag phase (hours) prior to the commencement of degradation of fraction $b$

c undegraded $=100-(\mathrm{a}+\mathrm{b})(\%)$

and ADF disappearance values of RSM only exceeded the values of zero time $(0 \mathrm{~h})$ incubation after 4 and $8 \mathrm{~h}$ of ruminal incubation. After $48 \mathrm{~h}$ of ruminal incubation, disappearance of NDF from the rape seed commodities was ranked in the order FRSM > rape seed $>$ RSM, whereas for ADF disappearance, the order was rape seed $>$ FRSM $>$ RSM.

Nonlinear parameter estimates and effective degradability values for NDF and ADF are presented in Table 3. Surprisingly, no lag phase prior to degradation of NDF and ADF was estimated for rape seed and FRSM, whereas for NDF and ADF of RSM, a lag phase occurred. The magnitude of the $b$ fraction of NDF declined in the order RSM > rape seed > FRSM, and that of ADF declined in the order RSM $>$ FRSM $>$ rape seed. The difference between the highest and lowest values, however, was only 7 and 6 percentage units for NDF and ADF, respectively. The rate constant of disappearance (c) of NDF and ADF largely differed between the three commodities. The values of $\mathrm{c}$ for NDF and ADF of rape seed were approximately four-fold and three-fold compared with those of FRSM. The $c$ values of RSM were intermediate. The effective NDF degradability at the low ruminal passage rate $(2 \% / \mathrm{h})$ was slightly higher for FRSM than for rape seed, whereas at the two higher ruminal passage rates, the values for rape seed were higher. The effective NDF degradability of RSM was 
TABLE 4

Effect of ruminal incubation time on concentration ( $\mathrm{g} / \mathrm{kg}$ dry matter) of macrominerals in rape seed commodities $^{a}$ and polyester bag residues after ruminal incubation

\begin{tabular}{|c|c|c|c|c|c|c|c|c|}
\hline & \multirow{2}{*}{ Feed } & \multicolumn{7}{|c|}{ Incubation time, $h$} \\
\hline & & 0 & 2 & 4 & 8 & 16 & 24 & 48 \\
\hline \multicolumn{9}{|l|}{ Calcium } \\
\hline RS & 4.45 & 10.0 & 11.4 & 14.2 & 21.4 & 22.5 & 18.6 & 9.3 \\
\hline RSM & 7.32 & 14.3 & 16.4 & 17.9 & 18.7 & 18.9 & 18.1 & 19.0 \\
\hline FRSM & 7.53 & 14.3 & 14.7 & 15.2 & 16.2 & 16.4 & 17.2 & 18.1 \\
\hline \multicolumn{9}{|c|}{ Phosphorus } \\
\hline RS & 9.21 & 6.61 & 7.46 & 6.24 & 2.97 & 2.68 & 1.99 & 8.53 \\
\hline RSM & 10.90 & 14.13 & 14.22 & 13.78 & 10.95 & 5.98 & 3.12 & 1.07 \\
\hline FRSM & 11.24 & 12.82 & 12.51 & 12.12 & 12.14 & 11.30 & 10.56 & 5.68 \\
\hline \multicolumn{9}{|c|}{ Magnesium } \\
\hline RS & 3.16 & 2.36 & 2.26 & 1.89 & 1.14 & 1.11 & 0.99 & 2.61 \\
\hline RSM & 4.45 & 4.21 & 4.32 & 3.67 & 2.96 & 2.57 & 2.41 & 2.14 \\
\hline FRSM & 1.55 & 0.97 & 1.68 & 3.56 & 4.49 & 4.27 & 4.20 & 4.41 \\
\hline \multicolumn{9}{|l|}{ Sodium } \\
\hline RS & 0.22 & 0.40 & 0.37 & 0.30 & 0.31 & 0.38 & 0.31 & 0.29 \\
\hline RSM & 1.28 & 0.49 & 0.70 & 0.62 & 0.55 & 0.42 & 0.32 & 0.19 \\
\hline FRSM & 0.94 & 0.32 & 0.50 & 0.40 & 0.47 & 0.37 & 0.42 & 0.31 \\
\hline
\end{tabular}

${ }^{\text {a }}$ RS, rape seed; RSM, rapeseed meal; FRSM, formaldehyde-treated rapeseed meal

always 10 to 15 percentage units lower than that of the two other feeds. With respect to the effective ADF degradability, feeds were ranked in the order rape secd $>$ FRSM $>$ RSM, and a maximum difference of almost 50 percentage units between rape seed and RSM was observed at a passage rate of $5 \% / \mathrm{h}$.

The concentration of macrominerals differed largely among commodities, mineral elements and incubation times (Table 4). The two meals had higher levels of macrominerals than the seed except $\mathrm{Mg}$. The $\mathrm{Mg}$ concentration was lower in the FRSM than in the RSM and rape seed. There was a general pattern that washing of the feeds ( $0 \mathrm{~h}$ disappearance) elevated the $\mathrm{Ca}$ and $\mathrm{P}$ concentrations and reduced the levels of $\mathrm{Mg}$ and $\mathrm{Na}$ with the only exception that the $0 \mathrm{~h}$ value of $\mathrm{Na}$ of rape seed was higher than that of the original feed. Compared with the $0 \mathrm{~h}$ values, the concentrations of $\mathrm{Ca}$ increased, whereas those of $\mathrm{P}$ decreased with increasing duration of incubation but the extent of the changes differed among feeds. Only the P content after $48 \mathrm{~h}$ of ruminal incubation of rape seed was greater than the $24 \mathrm{~h}$ value. Irrespective of the direction of the changes, the FRSM exhibited a moderate pattern of raising and declining $\mathrm{Ca}$ and $\mathrm{P}$ levels in the feed residues caused by ruminal incubation for different time periods, which 
TABLE 5

Effect of ruminal incubation time on disappearancc ${ }^{2}(\%)$ of macrominerals of rape seed commodities $^{\mathrm{b}}$

\begin{tabular}{|c|c|c|c|c|c|c|c|c|}
\hline & \multirow{2}{*}{$\begin{array}{l}\text { Washing } \\
\operatorname{loss}^{\mathrm{c}}\end{array}$} & \multicolumn{7}{|c|}{ Incubation time, $h$} \\
\hline & & 0 & 2 & 4 & 8 & 16 & 24 & 48 \\
\hline \multicolumn{9}{|l|}{ Calcium } \\
\hline RS & -69.2 & 25.7 & 26.9 & 18.9 & 23.3 & 55.7 & 68.7 & 87.3 \\
\hline RSM & -37.1 & 13.9 & 2.9 & 4.2 & 29.6 & 52.0 & 62.4 & 72.0 \\
\hline FRSM & -53.6 & 19.5 & 16.4 & 14.9 & 15.1 & 32.2 & 38.5 & 60.2 \\
\hline \multicolumn{9}{|c|}{ Phosphorus } \\
\hline RS & 46.0 & 54.8 & 55.7 & 67.2 & 90.2 & 95.1 & 96.9 & 89.3 \\
\hline RSM & 8.9 & 16.4 & 17.1 & 27.4 & 59.4 & 85.1 & 93.6 & 98.5 \\
\hline FRSM & 7.7 & 25.7 & 26.9 & 30.3 & 34.6 & 52.1 & 61.2 & 87.1 \\
\hline \multicolumn{9}{|c|}{ Magnesium } \\
\hline RS & 43.9 & 39.8 & 50.0 & 63.0 & 85.9 & 92.5 & 94.2 & 87.8 \\
\hline RSM & 33.6 & 28.3 & 27.5 & 44.4 & 68.5 & 81.6 & 85.8 & 91.1 \\
\hline FRSM & 49.1 & 42.0 & -0.6 & -110.3 & -148.3 & -85.8 & -58.6 & -2.6 \\
\hline \multicolumn{9}{|l|}{ Sodium } \\
\hline RS & -38.4 & 65.1 & 71.8 & 79.7 & 86.9 & 91.0 & 93.9 & 95.3 \\
\hline RSM & 72.8 & 84.5 & 78.5 & 82.7 & 89.3 & 94.5 & 96.6 & 98.5 \\
\hline FRSM & 72.7 & 74.8 & 60.5 & 69.0 & 65.7 & 78.5 & 78.9 & 90.6 \\
\hline
\end{tabular}

indicates a more steady release of $\mathrm{Ca}$ and $\mathrm{P}$ from FRSM than from either rape seed or RSM. As duration of ruminal incubation increased, the concentration of $\mathrm{Mg}$ decreased in the residues of rape seed (except after $48 \mathrm{~h}$ ) and RSM and increased largely in FRSM. For Na, however, an increase was observed for RSM, a decrease for rape seed and no clear direction of changes for the FRSM residues.

When averaged across feedstuffs, zero time $(0 \mathrm{~h})$ disappearance increased in the order $\mathrm{Ca}<\mathrm{P}<\mathrm{Mg}<\mathrm{Na}$. For each macromineral, there were differences between the feedstuffs. Generally, the $0 \mathrm{~h}$ disappearance values of $\mathrm{Ca}$ and $\mathrm{P}$ were lowest for RSM, intermediate for FRSM and highest for rape seed. With only few exceptions, percent disappearance of $\mathrm{P}, \mathrm{Mg}$ and $\mathrm{Na}$ from rape seed and RSM increased with longer incubation times (Table 5). The disappearance of $\mathrm{P}$ from FRSM was lower and slower than from the two other feeds. The disappearance values of $\mathrm{Mg}$ and $\mathrm{Na}$ of FRSM from 2 to $48 \mathrm{~h}$ and 2 to $8 \mathrm{~h}$, respectively, were even lower than the $0 \mathrm{~h}$ values, indicating a substantial net inflow of these two 
elements into the bags. Except for Mg of FRSM, the $48 \mathrm{~h}$ disappearance values of $\mathrm{P}, \mathrm{Mg}$ and $\mathrm{Na}$ of all three rape seed commodities were $>87 \%$. The highest values were observed for RSM. The pattern of ruminal Ca disappearance was different from that of the other macrominerals. The values of the water-soluble $\mathrm{Ca}$ fraction $(0 \mathrm{~h})$ of rape seed, RSM and FRSM were only similar after more than 2, 4 and $8 \mathrm{~h}$, respectively, of ruminal incubation. The ruminal disappearance of $\mathrm{Ca}$ from RSM and FRSM also was lower than that of P, Mg and Na. The $48 \mathrm{~h}$ disappearance values of $\mathrm{Ca}$ were 20 to 30 percentage units lower than for the other elements. Only rape seed reached a level of Ca disappearance of $>87 \%$ after $48 \mathrm{~h}$ of ruminal incubation.

\section{DISCUSSION}

The three rape seed commodities differed in fibre and macromineral contents and in characteristics of ruminal fibre degradation and macromineral disappearance. The NDF and ADF concentrations of rape seed and the NDF content of FRSM were much higher than those reported previously for rape seed (Ochodzki et al., 1995) and RSM (Slominski and Campbell, 1991; Moss and Givens, 1994). As values for fibre degradation and macromineral disappearance were very consistent, analytical errors can be excluded. Also, the fibre analyses were repeated by different persons and consistently gave identical results.

The few studies conducted so far on nutritive characteristics of rape seed fibre or hulls indicated low ruminal (Grenet and Barry, 1990) and whole-tract (Keller et al., 1995) digestibilities of fibre components. McKinnon et al. (1995) reported that digestible energy content of canola hulls for ram lambs was similar to that of a lucerne hay used in the same study but the hay had DM, NDF and ADF digestibilities of only 51,39 and $28 \%$, respectively. The effective NDF and ADF degradabilities of the same hulls at a ruminal passage rate of $5 \%$ were 19 and $12 \%$, respectively (McKinnon et al., 1995). The effective degradabilites of NDF and ADF of the three commodities used in the present study were much higher. Even at the highest ruminal passage rate and for the least degradable feed, RSM, the values for effective NDF and ADF degradability were 19 (NDF) and 10 (ADF) percentage units higher than those reported by McKinnon et al. (1995).

Bailey and Hironaka (1984) reported that treatment of canola meal with formaldehyde at a level of $5 \mathrm{~g} / \mathrm{kg}$ of meal reduced in situ disappearance of non-protein organic matter (DM - crude protein - ash). Surprisingly, in our study the effective degradabilities of NDF and ADF of FRSM were higher than those of RSM. The positive effect of formaldehyde treatment on fibre degradation might be related to the mode of application of formaldehyde on the RSM. Treatment was conducted under pressure, which may have weakened 
cell-wall structures, and by this facilitating and accelerating access of ruminal microorganisms to the cell-wall. The observation that no lag period was found prior to NDF and ADF degradation of FRSM supports this hypothesis. It is noteworthy, however, that NDF and ADF of FRSM also contained a considerable portion of the soluble a fraction. The rate constant of fibre degradation ranked the rape seed commodities in the order rape seed $>$ RSM $>$ FRSM, indicating that increasing strength of physical treatment decreased the degradation rate.

Concentrations of $\mathrm{Ca}, \mathrm{P}$ and $\mathrm{Mg}$ of rape seed were similar to the upper range values reported for 11 samples of Polish rape seed (Matyka et al., 1992) and those of RSM and FRSM were similar to the data summarized for canola meal by Bell (1993). For the macrominerals our data confirm that feeds produced from rape seed are a good source of macrominerals for ruminants (Bell, 1993). Except the concentration of $\mathrm{Mg}$ of FRSM was remarkably lower than reported previously (Bell, 1993). Because RSM and FRSM originated from the same batch of rape seed, it is obvious that the difference in Mg concentration between RSM and FRSM might be related to formaldehyde treatment. Moreover, only $\mathrm{Mg}$ in FRSM showed negative disappearance values, indicating net inflow of Mg into the bags, which additionally points to special effects of formaldehyde on $\mathrm{Mg}$ binding capacity of RSM.

There is a scarcity of data on ruminal release of minerals from rape seed and RSM. The in situ $\mathrm{P}$ disappearance from 5 samples of canola meal after $16 \mathrm{~h}$ of ruminal incubation ranged from 64 to $78 \%$ (Ingalls and Okemo, 1994). These values were lower than those observed for rape seed and RSM in our study but higher than that for FRSM. Phosphorus in rape seed and RSM appeared to be nearly completely available at the rumen level, as indicated by $24 \mathrm{~h}$ disappearance values of 97 and $94 \%$, respectively. The values of $P$ disappearance from FRSM were consistently lower up to $24 \mathrm{~h}$ of ruminal incubation. After $48 \mathrm{~h}$, however, P disappearance from FRSM was as high as $87 \%$. Thus, the time course of disappearance of $\mathrm{P}$ from FRSM indicated a slow yet steady ruminal release of this element. Because cell-wall digestion is highly sensitive to P deficiency in the rumen (Durand and Komisarczuk, 1988), the observed pattern of $P$ release from FRSM may be beneficial especially for cell-wall degrading microorganisms.

With the one exception of Mg in FRSM mentioned above, the disappearance of $\mathrm{Mg}$ and $\mathrm{Na}$ was $>90 \%$ after 24 or $48 \mathrm{~h}$ of ruminal incubation, indicating a high ruminal availability of these two elements in all three commodities. Within this time interval, however, the disappearance of the two elements followed a different pattern. More than $68 \%$ of total $\mathrm{Na}$ in rape seed and RSM were in the soluble fraction, whereas for $\mathrm{Mg}$, only 31 to $42 \%$ of the total $\mathrm{Mg}$ that disappeared during ruminal incubation was soluble. Flachowsky and Grün (1992) observed that in situ Mg disappearance of artificially dried Italian ryegrass 
and wheat straw was similar to DM disappearance when feeds were incubated in the rumen of sheep. In our study, Mg disappearance of rape seed and RSM was greater than DM disappearance (Südekum and Andree, 1997). Although rape seed and RSM had high concentrations of NDF providing a great number of binding sites for divalent cations that would favour cation exchange at the surfaces, ruminal disappearance of $\mathrm{Mg}$ of rape seed and RSM was always greater than zero for any time interval.

Within the first 2, 4 and $8 \mathrm{~h}$ of ruminal incubation, respectively, the values for Ca disappearance of rape seed, RSM and FRSM were lower than the respective $0 \mathrm{~h}$ values. This indicates that more $\mathrm{Ca}$ flowed into the bags and adhered to the feed particles than was released from the feeds during the observed time intervals. This supports observations that $\mathrm{Ca}$ plays a prominent role in cation exchange processes at cell-wall surfaces (Emanuele and Staples, 1990; Flachowsky and Grün, 1992; Flachowsky et al., 1994). After $48 \mathrm{~h}$ of ruminal incubation, the disappearance of $\mathrm{Ca}$ from the three commodities ranged from 60 to $87 \%$. Ledoux and Martz (1991) reported a similar variation for 5 forages and 10 diets containing these forages.

\section{CONCLUSIONS}

In the present study, detergent fibre fractions of rape seed, RSM and FRSM were more degradable ruminally than previous studies on ruminal degradation of hulls of rape seed or in vivo digestibility of NDF and ADF of rape seed had indicated. The general ranking of fibre degradabilties of the three commodities in decreasing order, namely rape seed $>$ FRSM $>$ RSM, further indicate that treatment with formaldehyde increased microbial access to cell-walls and may thus account for enhanced degradation compared with the untreated RSM. Our data confirm earlier observations that, based on mineral concentrations in the original feeds, feedstuffs produced from B. napus are a good source of macrominerals to ruminants. The slow but steady ruminal release of most macrominerals from all three commodities could have an additional positive effect on ruminal microorganisms and hence cell-wall degradation.

\section{ACKNOWLEDGMENTS}

This study was supported by grant 524/932 from the Union zur Förderung von Oel-und Proteinpflanzen (UFOP e. V., Bonn, Germany). The three rape seed commodities were kindly donated by A. Helmedach. We thank U. Lies for skilled analytical assistance. 


\section{REFERENCES}

Agricultural Research Council, 1984, The Nutrient Requirements of Ruminant Livestock, Suppl. No. 1. Commonwealth Agric. Bureaux, Farnham Royal

Bailey C.B., Hironaka R., 1984. Estimation of the rumen degradability of nitrogen and of nonprotein organic matter in formaldehyde-treated and untreated canola meal. Can. J. Anim. Sci. 64, 183-185

Bassler R. (Editor), 1976. Die chemische Untersuchung von Futtermitteln. Methodenbuch, Vol. 3 mit Ergänzungslieferungen 1983, 1988, 1993. VDLUFA-Verlag, Darmstadt

Bell J.M., 1993. Factors affecting the nutritional value of canola meal: A review. Can. J. Anim. Sci. $73,679-697$

Bell J.M., Shires A., 1982. Composition and digestibility by pigs of hull fractions from rape seed cultivars with yellow and brown seed coats. Can. J. Anim. Sci. 62, 557-565

Durand M., Komisarczuk S., 1988. Influence of major minerals on rumen microbiota. J. Nutr. 118, $249-260$

Emanuele S.M., Staples C.R., 1990. Ruminal release of minerals from six forage species. J. Anim. Sci. $68,2052-2060$

Flachowsky G., Grün M., 1992. Influence of type of diet and incubation time on major element release in sacco from Italian ryegrass, untreated and ammonia-treated wheat straw. Anim. Feed Sci. Technol. 36, 239-254

Flachowsky G., Schneider A., Ochrimenko W.I., Kronemann H., 1994. Calcium release from various roughages and influence of $\mathrm{Ca}$ on dry matter degradability of roughages in the rumen and apparent digestibility of ration. J. Appl. Anim. Res. 6, 43-57

Grenet E., Barry P., 1990. In vivo and in sacco digestibility and rumen microbial degradation of cell walls of soyabean and rape integuments and of dehydrated beet pulp in sheep, observed by scanning electron microscopy. J. Agric. Sci., Camb. 115, 429-435

Ingalls J.R., Okemo R.C., 1994. The bioavailability of phosphorus from canola mcal as measured by Holstein calves and mobile hag technique. Anim. Feed Sci. Technol. 47, 321-334

Keller T., Kracht W., Dänicke S., Jeroch H., 1995. Futterwert von Rapsschalen bei Schafen. VDLUFA-Schriftenreihe 40 (Kongressband 1995), 785-787.

Kirby L.K., Nelson T.S., 1988. Total and phytate phosphorus content of some fecd ingredicnts derived from grains. Nutr. Rep. Int. 37, 277-280

Ledoux D.R., Martz F.A., 1991. Ruminal solubilization of selected macrominerals from forages and diets. J. Dairy Sci. 74, 1654-1661

Matyka S., Jaśkicwicz T., Bogusz G., Korol W., 1992. A note on the chemical composition of low glucosinolate rape seed produced in North-Eastern Poland. J. Anim. Feed Sci. 1, 177-182

McDonald 1.M., 1981. $\Lambda$ revised model for the estimation of protein degradability in the rumen. $J$. Agric. Sci., Camb. 92, 251-252

McKinnon J.J., Mustafa A.F., Cohen R.D. H., 1995. Nutritional evaluation and processing of canola hulls for ruminants. Can. J. Anim. Sci. 75, 231-237

Moss A.R., Givens D.I., 1994. The chemical composition, digestibility, metabolisable energy content and nitrogen degradability of some protein concentrates. Anim. Feed Sci. Technol. 47, 335-351

Ochodzki P., Rakowska M., Bjergegaard C., Sørensen H., 1995. Studies on enzymatic fractionation, chemical composition and biological effects of dictary fibre in rape seed (Brassica napus L.). 1. Chemical composition of seeds and characteristics of soluble and insoluble dietary fibre of spring and winter type varieties of double improved oilseed rape. J. Anim. Feed Sci. 4, 127-138

Slominski B.A., Campbell L.D., 1991. The carbohydrate content of yellow-seeded canola. In: D.I. McGregor (Editor). Proceedings of GCIRC 8th International Rapeseed Congress, Vol. 5. Saskatoon, SK, pp. 1402-1405 
Südekum K.-H., Andree H., 1997. Evaluation of three rape seed commodities in the rumen of steers.

1. Degradation of dry matter and crude protein and disappearance of amino acids in situ.

J. Anim. Feed Sci. 6, 23-40

Tamminga S., van Vuuren A.M., van der Koelen C.J., Ketelaar R.S., van der Togt P.L., 1990. Ruminal behaviour of structural carbohydrates, non-structural carbohydrates and crude protein from concentrate ingredients in dairy cows. Neth. J. Agric. Sci. 38, 513-526

Van Soest P.J., Robertson J.B., Lewis B.A., 1991. Methods for dietary fiber, neutral detergent fiber, and nonstarch polysaccharides in relation to animal nutrition. J. Dairy Sci. 74, 3583-3597

Weisbjerg M.R., Bhargava P.K., Hvelplund T., Madsen J, 1990. Anvendelse af nedbrydningsprofiter i fodermiddelvurderingen. Beretning fra Statens Husdyrbrugsforsøg No. 679. Tjele, $33 \mathrm{pp}$.

\section{STRESZCZENIE}

Ocena wartości różnych rodzajów pasz rzepakowych w żwaczu buhajków. 2. Trawienie wlókna i uwalnianie makroelementów oznaczane metodą in situ

Szybkość i rozmiar trawienia frakcji wlókna oraz ubytek $\mathrm{Ca}, \mathrm{P}, \mathrm{Mg}$ i $\mathrm{Na}$ z nasion rzepaku, pockstrakcyjnej śruty rzepakowej zwykłej lub traktowanej formaldehydem, zawierającej w $1 \mathrm{~g}$ suchej masy mniej niż $8 \mu \mathrm{m}$ glukozynolanów, oznaczano inkubując te pasze w woreczkach z. tkaniny poliestrowej umieszcronych w żwaču 3 buhajków przez $0,2,4,8,16,24$ j 48 godzin. Otrzymane parametry rozkładu frakcji włókna wskazują, że wlókno nasion rzepaku może być trawione w większym stopniu niż to dotychczas przyjmowano. Frakcje wlókna poekstrakcyjnej śruty traktowanej formaldchydem byly trawione w większym stopniu niż śruty nic poddanej dzialaniu formaldehydu. Ffektywny rozkład NDF nasion rzepaku, przy zalozieniu tempa wyplywu treści ze żwacza 2, 5 i $8 \%$ /godz, osiągną1 wartości od 62 do $53 \%$, natomiast poekstrakcyjnej śruty rzepakowej od 52 do $38 \%$, a traktowanej formaldehydem od 65 do $49 \%$. Zawartość makroclementów i tempo ich uwalniania w żwaczu ze wszystkich badanych prób wskazujł, że wszystkie badane pasze rzepakowe były dobrym źródłem makroelementów dla przėzuwačy. Większość makroelementów była uwalniana szybciej z nasion rzepaku niz. z obydwóch śrut poekstrakcyjnych. Z poekstrakcyjnej śruty zwykłej większość makroelementów, w przeciwieństwie do włókna, miała tendencję do szybszego uwalniania niż ze śruty formaidehydowanej. 